\title{
機械式柱主筋外定着方式による最上階 RC 造 L 形接合部の構造性能 STRUCTURAL PERFORMANCE OF R/C L-SHAPED BEAM-COLUMN JOINTS USING MECHANICAL EXTERNAL ANCHORAGE OF COLUMN REINFORCEMENT
}

\author{
益尾＼cjkstart潔*, 堂下 航**, 足立将人***, 田川浩之**** \\ Kiyoshi MASUO, Wataru DOUSHITA, Masato ADACHI \\ and Hiroyuki TAGAWA
}

\begin{abstract}
The reinforcement detailing in L-shaped R/C beam-column joints at the roof-level is important for rationalization of design and construction of moment-resisting frame. In order to solve this problem, the authors proposed new reinforcement detailing using mechanical external anchorage of column reinforcement. Through this detailing, anchorage region is small enough to be hidden in the water-proof layer. In this study, such L-shaped R/C beam-column joints are tested. The experimental data shows that these joints have larger deformation capacity than with conventional anchorage. This is due to the formation of the strut mechanism in the joint. Consequently, the authors clarify that the proposed design formula can be applied for estimation of ultimate strength of these joints on the basis of experimental results.
\end{abstract}

Keywords : Mechanical External Anchorage, L-Shaped Joint, Reinforcement Detailing, Strut Mechanism, Ultimate Strength, Ductility 機械式柱主筋外定着, L 形接合部, 配筋詳細, ストラット機構, 終局而力, 変形能力

\section{1. はじめに}

鉄筋コンクリート骨組における最上階 L 形接合部内の柱，梁主筋 定着部の納まりは，特に太径鉄筋の場合，最上階だけでなく下階の 柱, 梁主筋定着部の納まりにも影響寸るので, 接合部配筋設計施工 の品質保証の点で重要である ${ }^{1)}$ 。

従来の定着方式による最上階 L 形接合部内の梁上端筋の定着力は, 折曲げ後の余長と出隅の引張側柱主筋との重ね継ぎ効果によって伝 達される ${ }^{2)}$ 。この場合, 柱主筋定着部は梁上端筋の下部に配置され, 梁端仕口面から折曲げ起点の間で，梁上端筋は上部から拘束されな いので，梁上端筋の付着力が早期に低下し，接合部必要横補強筋量 がト形接合部と比べて多い 2)。また, 柱, 梁主筋定着部が柱梁接合 部内で輻輳するので，接合部配筋詳細の納まりが難しい。以下，従 来の定着方式を柱主筋内定着方式と称する。

鉛直スタブ付き $\mathrm{L}$ 形接合部の場合, 柱主筋定着部からの押え効果 を期待できるので, 梁上端筋定着部は, 卜形接合部内の梁主筋定着 部と同様，梁上端筇を折曲げない機械式直線定着とすることができ る ${ }^{3)}$ 。しかし, 鉛直スタブは屋上に突出するので, 意匠計画上, 採 用されにくい。一方, 柱主筋定着部は, 梁上端筇の上部でも, 屋上 防水層の押えコンクリート厚さ以内に納まれば都合がよい。

これらより, 最上階梁上端筋を機械式直線定着とし, 同定着部の 上部に柱主筋定着部を配置し，柱主筋定着部を定着部拘束筋と称す
る補強筋で拘束するとともに，梁上端筋定着部の上部からかんざし 筋を挿入する接合部配筋詳細が考案された ${ }^{4), 5)}$ 。この配筋詳細を柱 主筋外定着方式と称する。本論文では, 柱主筋外定着方式による L 形接合部の構造性能を実験的に明らかにする。

筆者ら提案の柱主筋外定着方式と類似の接合部配筋詳細の実験が 田才ら $\left.{ }^{6)}, 7\right)$ にって行われている。田才ら提案の接合部配筋詳細で は,かんざし筋を配置せず, 定着部拘束筋の降伏強度を高めている。 これらの点が筆者ら提案の柱主筋外定着方式と異なる。

\section{2. 実験計画}

\section{1 試験体}

本実験は，表 1 に示すように，系列 I 〜 IVで構成され，試験体数 は計 16 体である。試験体は，実大の約 $1 / 2$ の縮小モデルであり，全 試験体ともに, 柱軸心から梁反曲点までのスパン長 $\ell$ の $1 / 2$ を $1700 \mathrm{~mm}$, 梁軸心から柱反曲点までの階高 hの $1 / 2$ を $1000 \mathrm{~mm}$ とした(図 2 参照)。 主な試験体の配筋詳細を図 1，材料試験結果を表 2 に示寸。

系列 I は柱主筋外定着と柱主筋内定着による L 形接合部の比較 実験 ${ }^{4)}$ ，系列 II は接合部せん断余裕度 $\mathrm{Qpu} / \mathrm{Qcu}_{\mathrm{c}}<1$ の柱主筋外定着効 果の確認実験 5)である。系列 I では，かんざし筋の配置方法の違い も調べている。系列 I , II ともに，梁幅と柱幅が同じ偏平梁とし， 梁せいが小さい分, 梁主筋本数を多くし, 終局時接合部入力せん断
本論文の一部は文献 4），5）で発表したものである。

* 一般社団法人建築構造技術支援機構 代表理事. 工博

**一般財団法人日本建築総合試験所構造部構造試験室 修士 (工学)

*** 一般財団法人日本建築総合試験所構造部構造試験室 博士 (工学)

**** 独立行政法人防災科学技術研究所 兵庫耐震工学研究センター Ph. D
Supporting Association for Building Structural Technology, Dr. Eng. Structural Eng. Dept., General Building Research Corporation, M. Eng.

Structural Eng. Dept., General Building Research Corporation, Dr. Eng. Hyogo Earthquake Engineering Research Center, NIED, Ph. D. 
力を高めている。

系列而は, 梁幅が柱幅よりも小さい標準型梁に対する柱主筋外定 着効果の確認実験であり, 併せて定着部拘束筋の鋼種 (SD490)の効 果を確認している ${ }^{5)}$ 。系列IVは, 梁主筋定着長さ $\ell \mathrm{ag}=12 \mathrm{db}=0.75 \mathrm{D}_{\mathrm{c}}$ と した長方形断面柱に対する柱主筋外定着効果の確認実験であり, 今 回，新たに行われた。dbは梁主筋直径，Dcは柱せいを示す。

\section{2 実験方法}

本実験では, 図 2 に示すように, 梁反曲点位置に両側ピン付き反 力受け治具を取り付けた 3 ヒンジラーメン架構について, L 形が閉 じる加力時を正加力時，その逆を負加力時とし，油圧ジャッキで梁 材軸位置に水平力を加えた。この場合，柱，梁に正加力時には圧縮 力, 負加力時には引張力が作用寸る。

表 1 実験計画

\begin{tabular}{|c|c|c|c|c|c|c|c|c|c|c|c|c|c|c|c|c|}
\hline \multirow[b]{2}{*}{$\begin{array}{l}\text { 系 } \\
\text { 列 }\end{array}$} & \multirow[b]{2}{*}{ 試験体 } & \multirow[b]{2}{*}{$\begin{array}{c}F_{c} \\
\left(\mathrm{~N} / \mathrm{mm}^{2}\right)\end{array}$} & \multicolumn{3}{|c|}{ 柱、梁断面 (mm) } & \multicolumn{4}{|c|}{ 梁引張主筋 } & \multicolumn{5}{|c|}{ 柱主筋 } & \multirow{2}{*}{$\begin{array}{c}\text { 定着部 } \\
\text { 拘束䇟 } \\
\text { 鋼種 }\end{array}$} & \multirow[b]{2}{*}{$\begin{array}{c}\text { かんざ } \\
\text { し筋 }\end{array}$} \\
\hline & & & $\begin{array}{c}\mathrm{Bc} \\
\times \mathrm{Dc} \\
\end{array}$ & Bg & Dg & 配筋 & 鋼種 & $\begin{array}{r}l_{\mathrm{ag}} \\
(\mathrm{mm})\end{array}$ & $\begin{array}{l}l \mathrm{ag} \\
/ \mathrm{db}\end{array}$ & 配筋 & 鋼種 & $\begin{array}{l}l \text { ac } \\
(\mathrm{mm})\end{array}$ & $\begin{array}{l}l \mathrm{ac} \\
/ \mathrm{db}\end{array}$ & $\begin{array}{l}l \text { ac } \\
/ \mathrm{Dg}\end{array}$ & & \\
\hline \multirow{6}{*}{ I } & $\mathrm{VL}-36-\mathrm{N}$ & \multirow{3}{*}{36} & \multirow{6}{*}{$\begin{array}{c}400 \\
\times 400\end{array}$} & 300 & 400 & $3-\mathrm{D} 19$ & \multirow{6}{*}{$\begin{array}{c}\text { SD } \\
390\end{array}$} & \multirow{6}{*}{300} & \multirow{6}{*}{15.8} & \multirow{6}{*}{$\begin{array}{c}12 \\
-\mathrm{D} 19\end{array}$} & \multirow{6}{*}{ SD390 } & 342 & 18.0 & 0.86 & - & $※ 1$ \\
\hline & $\mathrm{VL}-36-\mathrm{F} 1$ & & & \multirow{2}{*}{400} & \multirow{2}{*}{320} & \multirow{2}{*}{ 4-D19 } & & & & & & \multirow{2}{*}{340} & \multirow{2}{*}{17.9} & \multirow{2}{*}{1.06} & \multirow{2}{*}{ SD295 } & \$1 \\
\hline & $\mathrm{VL}-36-\mathrm{F} 2$ & & & & & & & & & & & & & & & $※ 2$ \\
\hline & $V L-54-N$ & \multirow{3}{*}{54} & & 300 & 400 & 4-D19 & & & & & & 342 & 18.0 & 0.86 & - & $※ 1$ \\
\hline & $\mathrm{VL}-54-\mathrm{F} 1$ & & & & & $5-D 19$ & & & & & & 340 & & 106 & & *1 \\
\hline & $\mathrm{VL}-54-\mathrm{F} 2$ & & & 400 & 320 & $5-119$ & & & & & & 340 & 17.9 & 1.06 & SDZ95 & $※ 3$ \\
\hline \multirow{4}{*}{ II } & LF36-B390-5 & \multirow{2}{*}{36} & \multirow{4}{*}{$\begin{array}{c}400 \\
\times 400\end{array}$} & \multirow{4}{*}{400} & \multirow{4}{*}{320} & 5-D19 & \multirow{2}{*}{$\begin{array}{c}\text { SD } \\
390 \\
\end{array}$} & \multirow{4}{*}{300} & \multirow{4}{*}{15.8} & & SD390 & & & & & \\
\hline & LF36-B390-8 & & & & & 8-D19 & & & & 12 & & 340 & 17.9 & 1.06 & SD295 & \\
\hline & LF54-B490-5 & & & & & 5-D19 & $\mathrm{SD}$ & & & $-D 19$ & SD490 & 340 & 17.9 & 1.00 & SDL95 & \\
\hline & LF54-B490-8 & 54 & & & & 8-D19 & 490 & & & & & & & & & \\
\hline & LF36-B390-A1 & & & & & & SD & & & & $\mathrm{SD}$ & & & & SD295 & \\
\hline III & LF36-B390-A2 & 36 & 400 & & & $4-D 19$ & 390 & & 158 & 12 & 390 & & & $1 \quad 05$ & SD490 & $æ 1$ \\
\hline III & LF50-B490-A1 & 50 & $\times 400$ & 300 & 400 & $4-D 19$ & $\mathrm{SD}$ & 300 & 15.8 & $-\mathrm{D} 19$ & $\mathrm{SD}$ & 420 & 22.1 & 1.05 & SD295 & \\
\hline & LF50-B490-A2 & & & & & & 490 & & & & 490 & & & & SD490 & \\
\hline IV & SL6-4-400-A & & 400 & & & & SD & & & 12 & $\mathrm{SD}$ & & & & SD295 & \\
\hline IV & SL6-4-400-B & 60 & $\times 305$ & 300 & 400 & $4-119$ & 390 & 228 & 12.0 & $-\mathrm{D} 22$ & 390 & 420 & 19.1 & 1.05 & SD490 & \\
\hline
\end{tabular}

【記号】 $\mathrm{F}_{\mathrm{c}}$ ：コンクリートの目標圧縮強度, $\mathrm{B}_{\mathrm{c}}$ ：柱幅， $\mathrm{D}_{\mathrm{c}}$ ：柱せい, $\mathrm{Bg}_{\mathrm{g}}$ ：梁幅， Dg ：梁せい

$l_{\mathrm{ag}}$ : 梁主筋定着長さ, $l_{\mathrm{ac}}$ : 柱主筋定着長さ, $\mathrm{db}$ ：梁, 柱主筋直径, $\mathrm{pj}$ wh : 接合部横補強筋

【共通配筋】 [梁主筋定着長さ比 $l \mathrm{ag} / \mathrm{Dc}_{\mathrm{c}}$ ] すべて 0.75

[接合部横補強筋] 2-D 10-3組 (p jwh $=0.44 \%$ (系列 I , II ), p jwh $=0.33 \%$ (系列 III， IV) )，鋼種：すべてSD295

[かんざし笳] (加力構面直交方向) ※1:2-D10-3 組, ※2:4-D 10-3組, ※3:6-D10-2組 (加力構面平行方向) 寸べて 2-D10-3組，かんざし筋鋼種：すべてSD295

(注記) 1) 系列 I の柱主筋内定着試験体 VL-36-N, VL-54-Nの梁上端筋の投影定着長さ $l \mathrm{dh}$ は $300 \mathrm{~mm}$ とし。

2) 系列 II の試験体LF36-B390-8, LF50-B490-8の梁上下主筋は2段配筋, それ以外の試験体の梁上下主筋はす心゙て1段配筋とした。
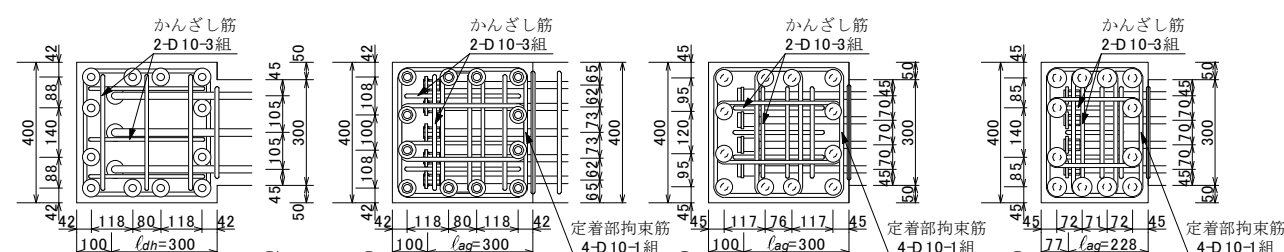

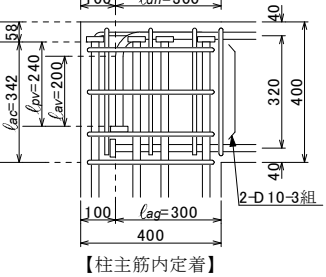

（系列 I、 II )

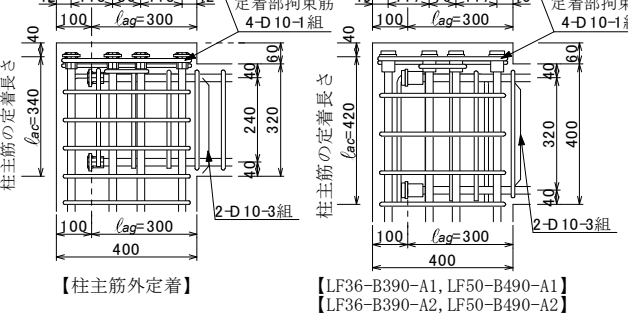

(系列 III)

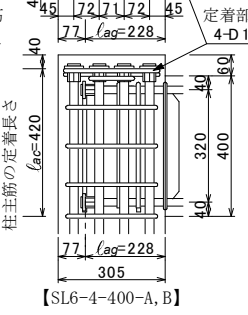

(系列IV)

(a) 接合部配筋詳細

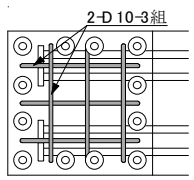

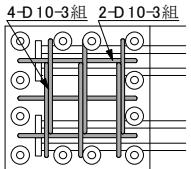

（系列 I 、II )

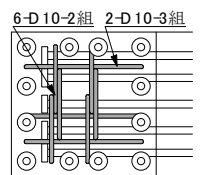

b）かんざし筋配置

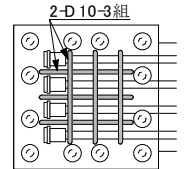

(系列 III)

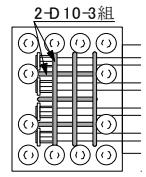

(系列IV)
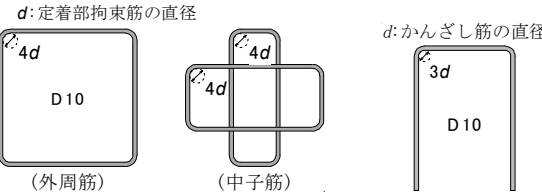

（c）定着部拘束筋およびかんざし筋の形状

図 1 主な試験体の配筋詳細 
表 2 材料試験結果

(a) コンクリート

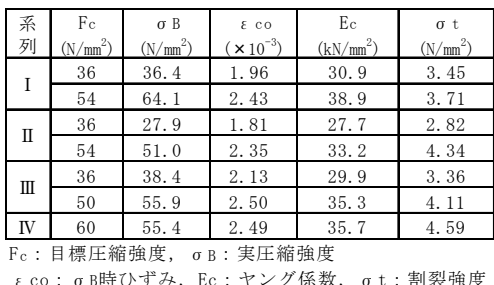

(b) 鉄筋

\begin{tabular}{|c|c|c|c|c|c|c|}
\hline $\begin{array}{l}\text { 系 } \\
\text { 列 }\end{array}$ & 使用部位 & $\begin{array}{l}\text { 呼び } \\
\text { 名 }\end{array}$ & 鋼種 & $\begin{array}{c}\sigma y \\
\left(\mathrm{~N} / \mathrm{mm}^{2}\right)\end{array}$ & $\left.\begin{array}{c}\sigma u \\
\left(\mathrm{~N} / \mathrm{mm}^{2}\right)\end{array}\right)$ & $\begin{array}{c}\text { 伸び } \\
(\%)\end{array}$ \\
\hline & 柱, 梁主筋 & D19 & SD390 & 430 & 641 & 19 \\
\hline \multirow[t]{2}{*}{1} & $\begin{array}{c}\text { 横補強筋 } \\
\text { 定着部拘筋 }\end{array}$ & D10 & SD295 & 353 & 512 & 28 \\
\hline & かんざし筋 & D10 & SD295 & 361 & 513 & 28 \\
\hline \multirow{4}{*}{ II } & 柱＼cjkstart涊主節 & D19 & SD390 & 454 & 654 & 20 \\
\hline & & & SD490 & 532 & 737 & 17 \\
\hline & $\begin{array}{c}\text { 横補玧筋 } \\
\text { 定着部拘束筋 } \\
\end{array}$ & D10 & SD295 & 376 & 538 & 26 \\
\hline & かんざし筋 & D10 & SD295 & 356 & 496 & 30 \\
\hline \multirow{5}{*}{ III } & 柱＼cjkstart泳主箱 & D19 & SD390 & 440 & 634 & 19 \\
\hline & & & SD490 & 503 & 663 & 17 \\
\hline & \begin{tabular}{c|c|} 
横補強筋 \\
\end{tabular} & D10 & SD295 & 347 & 485 & 29 \\
\hline & 定着部拘束筋 & & SD490 & 507 & 822 & 14 \\
\hline & かんざし筋 & D10 & SD295 & 345 & 463 & 31 \\
\hline \multirow{5}{*}{ IV } & 梁主筋 & D19 & \multirow{2}{*}{ SD390 } & 430 & 625 & 20 \\
\hline & 柱主筋 & D22 & & 430 & 632 & 21 \\
\hline & 横補強筋 & D10 & SD295 & 312 & 475 & 30 \\
\hline & 定着部拘束筋 & & SD490 & 549 & 785 & 19 \\
\hline & かんざし筋 & D10 & SD295 & 364 & 517 & 26 \\
\hline
\end{tabular}

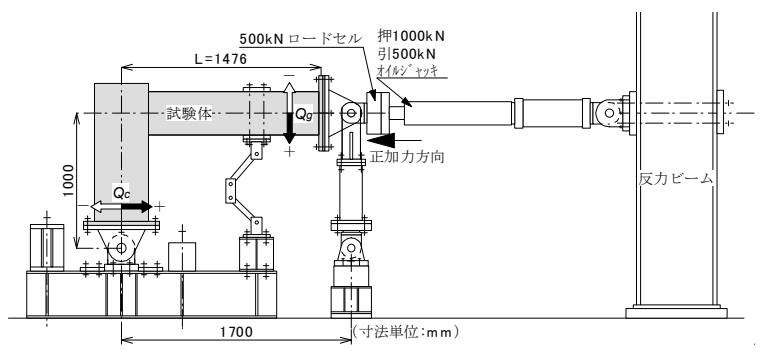

図 2 載荷装置

載荷履歴は，目標層間変形角 $\mathrm{R}=5,10,20,30,40,60 \times 10^{-3} \mathrm{rad}$. での 2 サイクルずつの正負交番繰返し載荷およびその後の正加力方向へ の単調載荷とした。

\section{3. 実験結果および考察}

\section{1 荷重一変形関係および破壊性状}

\section{1.1 系列 I}

系列 $\mathrm{I}$ の主な試験体の柱せん断力 $\mathrm{Qc}$ 一層間変形角 $\mathrm{R}$ 関係を図 3 , 実験因子ごとの $Q_{c} / Q_{c u}-R$ 関係正加力時包絡線を図 4, 代表的試験体 のひび割れ状況を写真 1 に示す。図 3 中には主な発生現象および限 界層間変形角実験值 R80, 図 4 中には接合部せん断余裕度 $\mathrm{Qpu} / \mathrm{Qcu}$ を 併記した。R80 は耐力が最大耐力実験值 Q $\max$ の 80\%に低下した時の層 間変形角実験值であり，Qpu は接合部せん断終局耐力時柱せん断力， Qcuは梁曲げ終局耐力時柱せん断力である(4.1.1 項 参照)。

各試験体ともに, $\mathrm{R}=5 \times 10^{-3} \mathrm{rad}$. 程度で接合部せん断ひび割れ, $\mathrm{R}=6$ $\sim 8 \times 10^{-3} \mathrm{rad}$. 程度で梁主筋引張降伏が発生した。内定着試験体では, 梁上端筋に沿った付着ひび割れが進展し, 柱梁接合部の出隅で柱主 筋の定着破壊が顕著となり, その後, 耐力が著しく低下した(写真 1 (a) 参照)。外定着試験体では, 接合部せん断ひび割れと梁端曲げ ひび割れが進展するとともに， $\mathrm{R}=30 \sim 60 \times 10^{-3} \mathrm{rad}$. まで耐力が上昇 し, 最大耐力 $Q$ max に達した。破壊形式は, かんざし筋の組数が多い
試験体 VL-36-F2, VL-54-F2 では梁曲げ破壊型，それ以外の試験体で は梁曲げ降伏後の接合部せん断破壊型と判別された。

外定着試験体の最大耐力および変形性能は, 図 4 に示すように, 内定着試験体よりも明らかに向上し，外定着試験体の限界層間変形 角実験值 R80 は，いずれも $60 \times 10^{-3} \mathrm{rad}$. 程度以上となった。また、 柱主筋外定着の場合，下記の効果が認められた。

(1) 定着部拘束筋の効果によって，柱主筋の定着耐力が向上した。

(2) 柱主筋定着部から派生するストラットの効果によって，梁上端 筋の定着耐力および梁上端筋のみ込み部の付着耐力，ならびに 柱梁接合部のせん断耐力が向上した。

(3) 梁上端筋上部から挿入したかんざし筋は梁上端筋の上面押し出 し破壞の防止効果を有し，その効果は加力直交方向のかんざし 筋の組数を増やすと向上した(図 1 (b) 参照)。上面押し出し破壊 は，文献 8)によるかんざし筋なしの小梁主筋定着実験で観察さ れた破壊形式である。

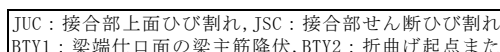

BTY1：梁端仕口面の梁主筋降伏, BTY2：折曲げ起点または定着金物近傍の梁主筋降伏 JHY：接合部横補強筋降伏, SCTY：定着部拘束筋降伏
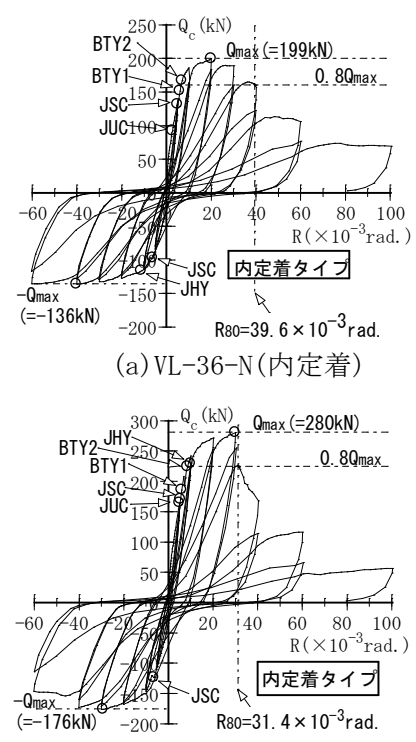

(c) VL-54-N (内定着) (a) VL-36-N (内定着)

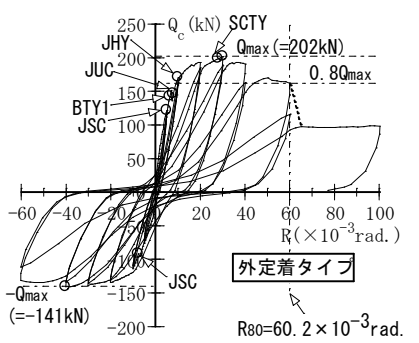

(b) VL-36-F1 (外定着)

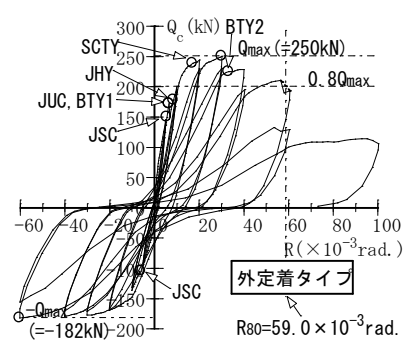

(d) VL-54-F1 (外定着)
図 3 系列 $\mathrm{I}$ の主な試験体の柱せん断力 $\mathrm{Qc}_{\mathrm{c}}$ 一層間変形角 $\mathrm{R}$ 関係

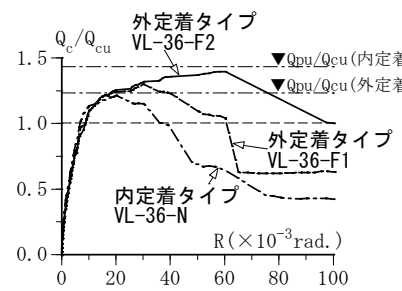

(a) Fc36 試験体

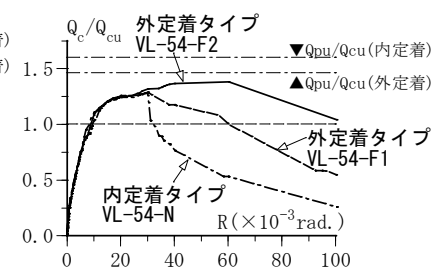

(b) Fc54 試験体
図 4 系列 $\mathrm{I}$ の実験因子ごとの $\mathrm{Q}_{c} / \mathrm{Q}_{\mathrm{cu}}-\mathrm{R}$ 関係正加力時包絡線

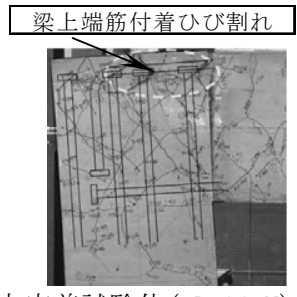

(a) 内定着試験体 (VL-36-N)

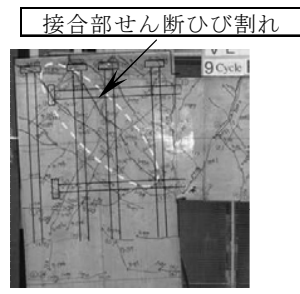

(b) 外定着試験体 $(\mathrm{VL}-36-\mathrm{F} 1)$
写真 1 系列 $\mathrm{I}$ の代表的試験体のひび割れ状況 $\left(\mathrm{R}=40 \times 10^{-3} \mathrm{rad}\right.$. 時) 


\section{1.2 系列 II}

系列 II の実験因子ごとの $\mathrm{Qc} / \mathrm{Qcu}_{\mathrm{cu}}-\mathrm{R}$ 関係正加力時包絡線を図 5 に 示す。各試験体ともに, $\mathrm{R}=5 \times 10^{-3} \mathrm{rad}$. 程度で接合部せん断ひび割れ が発生し, $\mathrm{R}=18 \sim 20 \times 10^{-3} \mathrm{rad}$. で最大耐力 $\mathrm{Q}_{\max }$ に達した。限界層間 変形角実験值 R80 は, Qpu/Qcu<1の試験体では 23. 9 35. 8× 10 ${ }^{-3} \mathrm{rad}$. であり，Qpu/Qcu=1.01 の試験体 LF54-B490-5 では 44.7×10-3 rad. で ある。Qpu/Qcu は接合部せん断余裕度を示す。破壊形式は, 試験体 LF54-B490-5 では梁曲げ降伏後の接合部せん断破壊型, それ以外の 試験体では接合部せん断破壊型と判別された。

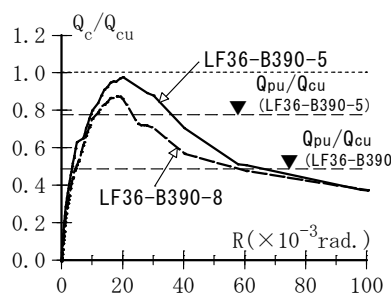

(a) Fc36 試験体

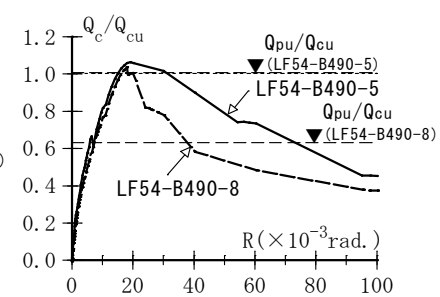

(b) Fc54 試験体
図 5 系列 II の実験因子ごとの $\mathrm{Qc}_{\mathrm{c}} / \mathrm{Q}_{\mathrm{cu}}-\mathrm{R}$ 関係正加力時包絡線

\section{1.3 系列 III}

系列 III の実験因子ごとの $\mathrm{Q}_{\mathrm{c}} / \mathrm{Q}_{\mathrm{cu}}-\mathrm{R}$ 関係正加力時包絡線を図 6 に 示す。各試験体ともに, $\mathrm{R}=5 \times 10^{-3} \mathrm{rad}$. 程度で接合部せん断ひび割れ が発生し， $\mathrm{R}=18 \sim 30 \times 10^{-3} \mathrm{rad}$. で最大耐力 $\mathrm{Qmax}$ に達した。限界層間 変形角実験值 R80 は，定着部拘束筋鋼種 SD295 の試験体では 31.2

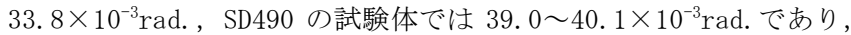
定着部拘束筋鋼種をSD295 から SD490 に高めると, 変形性能が向上 した。接合部せん断余裕度 Qpu/Qcuは, Fc36 試験体では 1. 09, Fc50 試験体では 1.24 であり, 各試験体ともに, 破壊形式は梁曲げ降伏後 の接合部せん断破壊型と判別された。

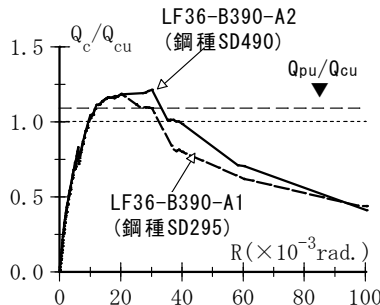

(a) Fc36 試験体

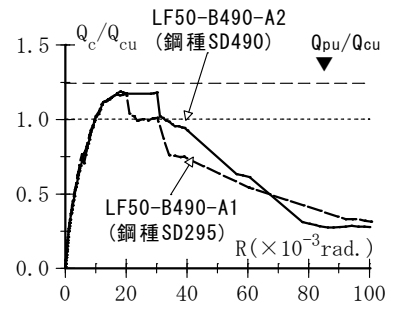

(b) Fc50 試験体
図 6 系列IIII 実験因子ごとの $Q_{c} / Q_{c u}-R$ 関係正加力時包絡線

\section{1.4 系列 $\mathrm{V}$}

系列IVの実験因子ごとの $\mathrm{Qc}_{\mathrm{c}} / \mathrm{Q}_{\mathrm{cu}}-\mathrm{R}$ 関係正加力時包絡線を図 7 に 示す。両試験体ともに, $\mathrm{R}=6 \times 10^{-3} \mathrm{rad}$. 程度で接合部せん断ひび割れ， $\mathrm{R}=9 \times 10^{-3} \mathrm{rad}$. 程度で梁主筋と接合部横補強筋の引張降伏, $\mathrm{R}=12 \sim 20$ $\times 10^{-3} \mathrm{rad}$. 時に定着部拘束筋の引張降伏が発生した後, 接合部せん 断ひび割れ幅の拡大に伴い, 最大耐力 Q max に達した。限界層間変形 角実験值 R80 は，定着部拘束筋鋼種 SD295 の試験体 SL6-4-400-A で

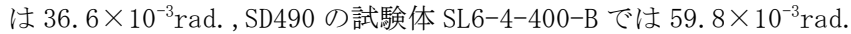
である。すなわち, 梁主筋定着長さ $\ell_{\mathrm{ag}}=12 \mathrm{db}=0.75 \mathrm{D}_{\mathrm{c}}$ でも, 柱主筋外 定着とし，定着部拘束筋鋼種をSD295 から SD490 に高めると，40× $10^{-3} \mathrm{rad}$. 以上の変形性能を確保できた。両試験体ともに, 接合部せ ん断余裕度 Qpu/Qcuは 1.10 であり, 破壊形式は梁曲げ降伏後の接合
部せん断破壊型であると判別された。

写真 2 に示すように，系列IV試験体でも，柱梁接合部の出隅から 発生する主要なせん断ひび割れは梁上端筋定着部と交差するので, 柱主筋定着部から延びるストラットによる押え効果が梁上端筋の定 着力の確保に寄与したと考えられる。

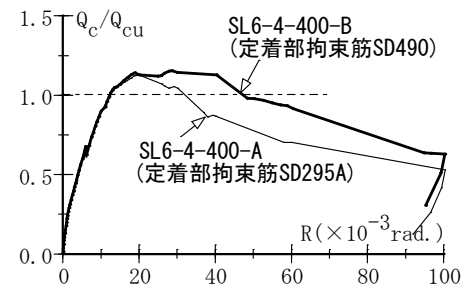

図 7 系列IVの実験因子ごとの

$Q_{c} / Q_{c u}-R$ 関係正加力時包絡線

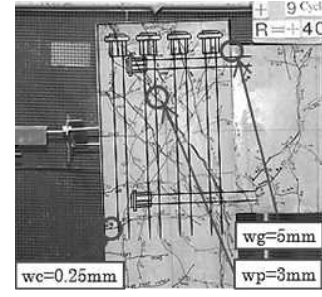

写真 2 系列IVSL6-4-400-B の ひび割れ状況 $\left(\mathrm{R}=40 \times 10^{-3} \mathrm{rad}\right.$. 時 $)$

\section{2 定着部拘束筋と接合部横補強筋のひずみ分布}

系列III試験体の定着部拘束筋と接合部横補強筋のひずみ測定位置 を図 8, 正加力所定時のひずみ $\varepsilon$ H1〜 $\varepsilon$ H5 分布を図 9 に示す。

図 9 によると, 定着部拘束筋鋼種 SD490 の場合も, SD295 と同様, 定着部拘束筋から接合部中央までの横補強筋ひずみ $\varepsilon$ H1 $\sim$ H 3 が増 加し, 梁曲げ降伏 $\left(\mathrm{R}=10 \times 10^{-3} \mathrm{rad}\right.$. 程度 $)$ 後, 概ね, 降伏ひずみ $\varepsilon$ y 超えた。すなわち，柱主筋外定着試験体では，SD295，SD490の定着 部拘束筋ともに，L 形が閉じる正加力時の場合，梁上端筋が引張力 を受けると，定着部拘束筋と接合部横補強筋ひずみが発現し，定着 部拘束筋による補強効果を期待できる。
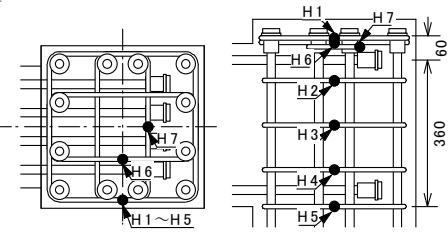

図 8 定着部拘束筋と接合部横補強筋のひずみ測定位置

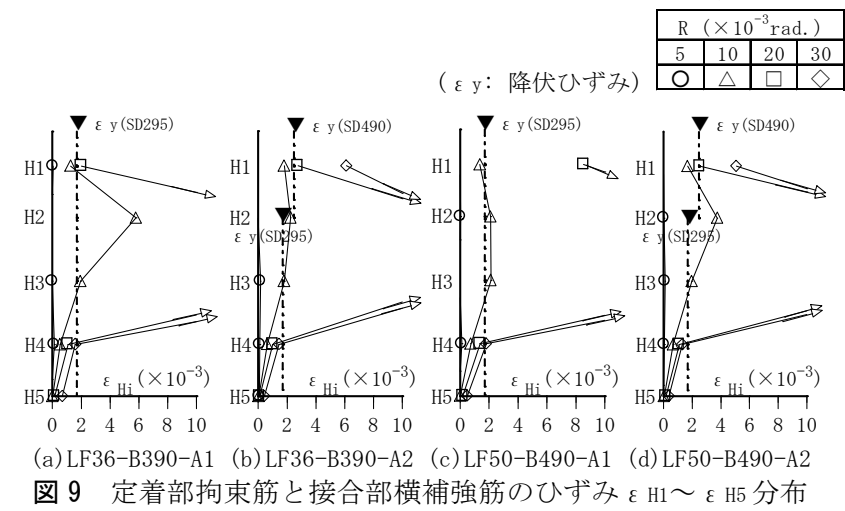

\section{3 かんざし筋ひずみの推移}

系列而試験体のかんざし筋のひずみ測定位置を図 10 , 正加力所 定時のかんざし筋の加力構面平行方向ひずみ $(\varepsilon$ K1， $\varepsilon$ K2， $\varepsilon$ K3 3 おおよ び直交方向ひずみ $(\varepsilon K 4, \varepsilon$ K5) の推移を図 11 に示す。同図によると,

1）加力構面平行方向 $\varepsilon \mathrm{K} 1$ の降伏ひずみ $\varepsilon \mathrm{y}$ 到達時 $\mathrm{R}$ は, 定着部拘束

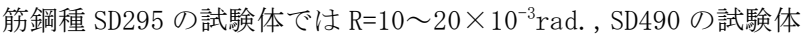
では $\mathrm{R}=10 \sim 30 \times 10^{-3} \mathrm{rad}$. であり，SD490 の試験体 LF50-B490-A2 では, 加力構面直交方向 $\varepsilon$ K4 も $\mathrm{R}=20 \times 10^{-3} \mathrm{rad}$. 時に, 降伏ひず み $\varepsilon \mathrm{y}$ に達した。

2）各試験体ともに，加力構面平行方向，直交方向に係わらず，出 
隅側柱主筋定着部に近いかんざし筋足部のひずみ $(\varepsilon$ K1 と $\varepsilon$ K 4$)$ が最大值となった。すなわち, かんざし筋ひずみは, 梁上端筋 定着部の上面への移動に伴って発現したと考えられる。

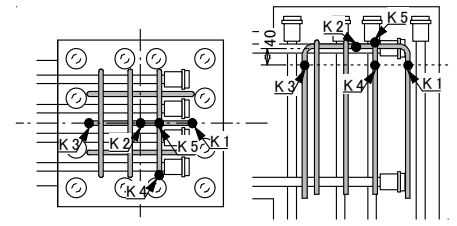

図 10 かんざし筋ひずみの測定位置

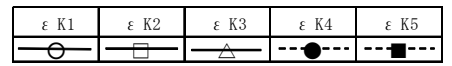

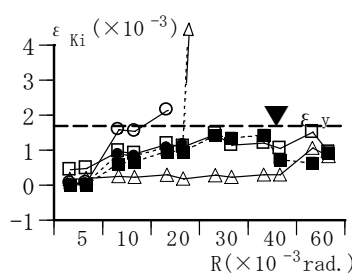

(a) LF36-B390-A1

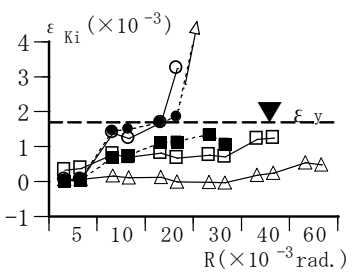

(c) LF50-B490-A1

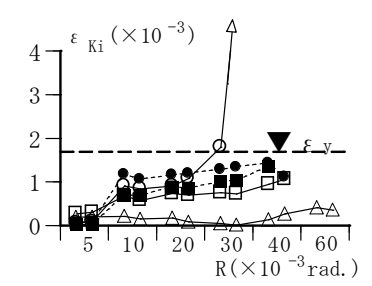

(b) LF36-B390-A2

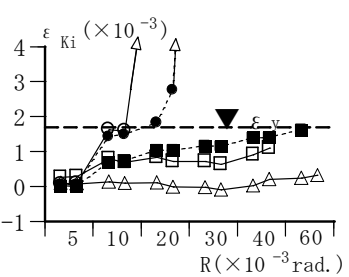

(d) $\mathrm{LF} 50-\mathrm{B} 490-\mathrm{A} 2$
図 11 かんざし筋ひずみ $\varepsilon$ K1 $\sim \varepsilon$ K5 の推移

\section{4 定着部拘束筋引張力に関する検討}

\section{4.1 検討方法}

梁上端筋が引張側の場合, 定着部拘束筋は, (1)柱主筋定着部から 派生する鉛直構面内ストラットの抵抗機構(図 12 (a)), (2)梁上端筋 定着部から派生する水平構面内ストラットの抵抗機構 (図 12 (b)) の 形成に寄与すると考えられる。

図 (a)の場合, 柱主筋定着部から延びる鉛直構面内ストラットと梁 上端筋定着部が重なり, 梁上端筋定着部に下向きの押え力が作用す るので, 梁上端笳の定着力が向上し, 接合部せん断耐力が高まると 考えられる。この場合, 外周筋と中子筋からなる定着部拘束筋の全 引張力 $\mathrm{TH}$ は, 鉛直構面内ストラットの水平分力と釣り合う。

下向きの押え力には，梁上端筋上部から挿入されるかんざし筋の 引き抜き抵抗が寄与する。また, 定着部拘束筋の全引張力 $\mathrm{TH}$ は, 図 (b) に示すように, 梁上端筋定着部から延びる水平構面内ストラット を介して, 梁端仕口面での梁上端筋の全引張力 $\mathrm{Tg}$ から伝達される梁 上端筋の定着力と釣り合う。以上の考察を基に，下記の定着部拘束 筋の引張力伝達係数 $(\gamma \mathrm{Hg}, \gamma \mathrm{Hc})$ について検討する。

$\gamma \mathrm{Hg}=\mathrm{TH} / \mathrm{Tg}$ : 梁上端筋に対する引張力伝達係数

$\gamma \mathrm{Hc}=\mathrm{TH} / \mathrm{T}_{\mathrm{cf}}$ : 最外縁柱主筋に対する引張力伝達係数

$\mathrm{TH}$ : 定着部拘束筋の全引張力

$\mathrm{T}_{\mathrm{g}}$ : 梁端仕口面での梁上端筋の全引張力

$\mathrm{T}_{\mathrm{cf}}$ : 柱端仕口面での出隅側・最外縁柱主筋の全引張力

$\mathrm{TH}, \mathrm{T}_{\mathrm{g}}, \mathrm{T}_{\mathrm{cf}}$ は，鉄筋ひずみ測定值 $(\varepsilon \mathrm{H} 1,6, \varepsilon \mathrm{g} 2,6, \varepsilon \mathrm{C} 2)$ を用い，完全 弾塑性型の応力ーひずみ関係を仮定して算出する。 $\varepsilon$ H1, 6 は定着部
拘束筋の引張ひずみ， $\varepsilon \mathrm{g} 2,6$ は梁端仕口面での梁上端筋の引張ひず み, $\varepsilon \mathrm{C} 2$ は柱端仕口面の出隅側・最外縁柱主筋の引張ひずみである (図 8 および図 13 参照)。

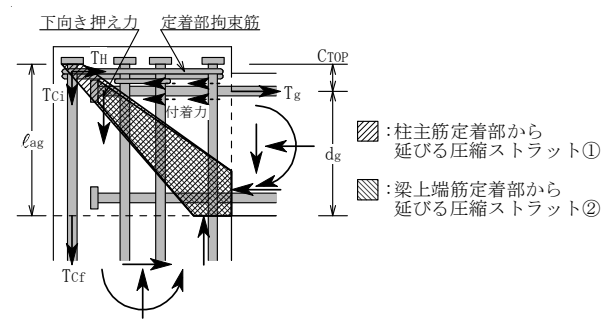

(a) 鉛直構面内ストラット

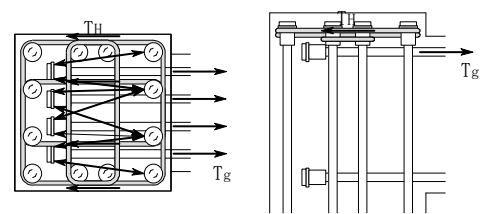

(b) 水平構面内ストラット

図 12 柱主筋外定着方式による定着部拘束筋に係わる抵抗機構

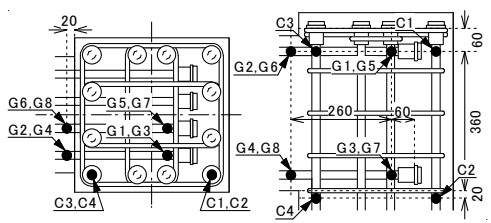

図 13 梁主筋および柱主筋筋のひずみ測定位置

\subsection{2 検討結果}

（1）梁上端筋に対する引張力伝達係数 $\gamma \mathrm{Hg}$ の推移

系列 III, IV の梁上端筋に対寸る引張力伝達係数 $\gamma \mathrm{Hg}(=\mathrm{TH} / \mathrm{Tg})$ の推 移を図 14 に示す。同図中には、梁上端筋に対する引張力基準伝達係 数 $\gamma$ Hgo $(=\mathrm{THy} / \mathrm{Tgy})$ を併記した。THy は定着部拘束筋の全降伏引張力, $T_{g y}$ は梁上端筋の全降伏引張力であり，系列III，IVの接合部せん断余 裕度 Qpu/Qcuは1.09〜1.24である。

同図によると, 各試験体ともに, 最大耐力時の $\gamma \mathrm{Hg}$ は引張力基準 伝達係数 $\gamma$ Hgo と同程度の值になった。すなわち, 梁曲げ降伏先行型 の場合, 最大耐力時の定着部拘束筋の全引張力 $\mathrm{TH}$ は, 梁端仕口面で の梁上端筋の全引張力 $\mathrm{Tg}$ から伝達される梁上端筋の定着力と釣り 合い， $\gamma$ Hg は $\gamma$ Hgo とほぼ一致したと考えられる。

(系列而の図中の黒塗り印：最大耐力時)

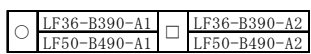

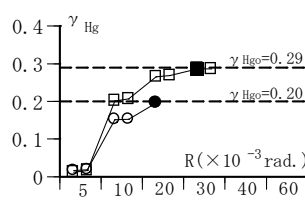

(Fc36 試験体)

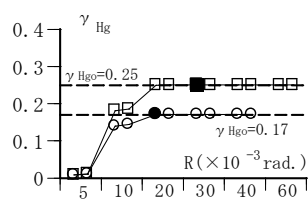

(Fc50 試験体) (a) 系列 III

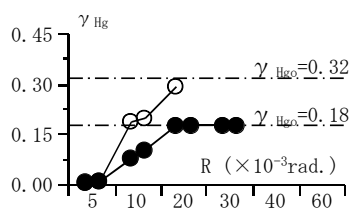

: SL6-4-400-A

(b) 系列IV

図 14 梁上端筋に対する引張力伝達係数 $\gamma \mathrm{Hg}$ の推移 
（2）最外縁柱主筋に対する引張力伝達係数 $\gamma \mathrm{Hc}$ の推移

系列 IIII, IV の最外縁柱主筋に対する引張力伝達係数 $\gamma \mathrm{Hc}\left(=\mathrm{TH} / \mathrm{T}_{\mathrm{cf}}\right)$ の推移を図 15 に示す。同図中には, 最外縁柱主筋に対する引張力基 準伝達係数 $\gamma$ Hco $\left(=\mathrm{THy}_{\mathrm{y}} / \mathrm{T}_{\mathrm{cy}}\right)$ を併記した。Tcy は, 梁降伏時の引張側柱 主筋の全引張力であり， $\mathrm{T}_{\mathrm{cy}}=\mathrm{act} \cdot \sigma \mathrm{cy} /\left(\mathrm{c} \mathrm{Q}_{\mathrm{cu}} / \mathrm{cQgu}\right)$ として算出した。 act， $\sigma$ cy は柱主筋の断面積および降伏強度，cQcu，cQgu は柱曲げ終局 耐力時および梁曲げ終局耐力時の柱せん断力である。

同図によると, 各試験体ともに, 層間変形角 $\mathrm{R}=10 \times 10^{-3} \mathrm{rad}$. 以降, $\gamma$ Hc は $\gamma$ Hcoに漸近した。すなわち, 梁曲げ降伏先行型のため, 柱端 仕口面の出隅側最外縁柱主筋の全引張力 T cf は, 梁降伏時の引張側 柱主筋の全引張力 $\mathrm{T}_{\mathrm{cy}}$ と近い值になったと考えられる。

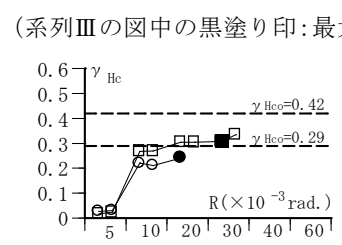

(Fc36 試験体)

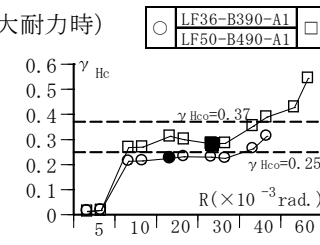

(Fc50 試験体) (a) 系列 III

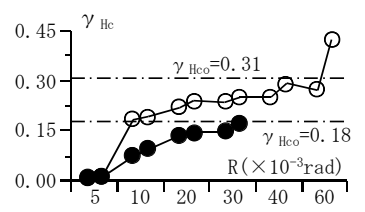

- - : SL6-4-400-A
- : SL6-4-400-B

(b) 系列IV

図 15 最外縁柱主筋に対する引張力伝達係数 $\gamma \mathrm{Hc}$ の推移

\section{4. 終局耐力および変形性能}

\section{1 終局耐力}

\section{1.1 検討方法}

柱主筋外定着による L 形部分架構の場合, 柱主筋内定着 ${ }^{9)}$ と同様, 梁または柱の曲げ終局耐力時柱せん断力 Q $\mathrm{cu}$ を式 (1), 接合部せん断 終局耐力時柱せん断力 Qpu を式(5)で算定する。

$$
\begin{aligned}
& Q_{c u}=\min \left(c Q_{c u}, \quad \mathrm{Qgu}\right) \\
& \mathrm{cQcu}=2 \mathrm{Mcuo}_{\mathrm{c}} /\left(\eta \mathrm{c} \cdot \mathrm{ho}_{\mathrm{o}}\right) \\
& \text { : 柱曲げ終局耐力時柱せん断力 } \\
& c Q g u=\left\{2 \mathrm{Mguo} /\left(\eta \mathrm{g} \cdot \ell_{\mathrm{o}}\right)\right\} \cdot(\ell / \mathrm{h}) \\
& \text { : 梁曲げ終局耐力時柱せん断力 } \\
& \eta \mathrm{c}=1 \mp\left(\mathrm{jtco} / \mathrm{ho}_{\mathrm{o}}\right) \cdot(\mathrm{h} / \ell), \quad \eta \mathrm{g}=1 \mp\left(\mathrm{jtg} / \ell_{\mathrm{o}}\right) \cdot(\ell / \mathrm{h})
\end{aligned}
$$

Mcuo, Mguo：柱および梁の基準曲げ終局耐力

h : 階高, ho：柱内法高さ

$\ell$ : スパン長, $\ell$ o: 梁内法スパン長

$\mathrm{jtg}$ : 梁上下主筋の重心間距離

$j \mathrm{tco}$ : 柱両側最外縁主筋の中心間距離

式(4)の $\eta \mathrm{c}$ と $\eta \mathrm{g}$ の右辺のそれぞれ第 2 項の前に付した符号は，L 形が閉じる正加力時には一，L 形が開く負加力時には+とする。

Qpu $=\min ($ Qpuh, Qpuv)

Qpuh $=2 V_{\text {puh }} / \xi_{\mathrm{h}}, \quad$ Qpuv $=2 \mathrm{~V}_{\text {puv }} / \xi_{\mathrm{v}}$

: 水平方向, 鉛直方向の接合部せん断終局耐力時柱せん断力

$\mathrm{V}_{\text {puh }}=\kappa \mathrm{u} \cdot \phi \cdot \mathrm{F}_{\mathrm{j}} \cdot \mathrm{b}_{\mathrm{j}} \cdot \mathrm{D}_{\mathrm{jh}}, \quad \mathrm{V}_{\text {puv }}=\kappa \mathrm{u} \cdot \phi \cdot \mathrm{F}_{\mathrm{j}} \cdot \mathrm{b}_{\mathrm{j}} \cdot \mathrm{D}_{\mathrm{jv}}$

: 水平方向, 鉛直方向の接合部せん断終局耐力 $\xi_{\mathrm{h}}=(\mathrm{h} / \ell) \cdot\left(\ell_{\mathrm{o}} / \mathrm{jtg}_{\mathrm{tg}}\right)-1, \quad \xi_{\mathrm{v}}=\left(\mathrm{ho}_{\mathrm{o}} / \mathrm{jtco}\right)-(\mathrm{h} / \ell)$

$\mathrm{F}_{\mathrm{j}}=0.8 \sigma \mathrm{B}^{0.7}$

$\kappa \mathrm{u}:$ 柱梁接合部の形状係数

(正加力時) $\kappa \mathrm{u}=0.6$, (負加力時) $\kappa \mathrm{u}=0.4$

$\phi$ : 直交梁の有無による補正係数（直交梁なしの場合） $\phi=0.85$

$\mathrm{b}_{\mathrm{j}}$ : 接合部有効幅, $\sigma \mathrm{B}$ ：コンクリートの圧縮強度 $\left(\mathrm{N} / \mathrm{mm}^{2}\right)$

$D_{j h}, D_{j v}$ : 水平方向, 鉛直方向の接合部有効せい

本検討では，柱主筋外定着の場合も，柱主筋内定着と同様，接合 部有効せいは, D jh= $\ell \mathrm{ag}, \mathrm{D}_{\mathrm{j} v}=\ell \mathrm{ac}$ とする。 $\ell \mathrm{ag}$ は梁主筋定着長さ, $\ell \mathrm{ac}$ は柱主筋定着長さを示す。

\section{1.2 検討結果}

柱主筋外定着試験体 $($ : 14 体) および直交梁なしの柱主筋内定着 試験体 $(\bigcirc: 31 \text { 体 })^{4), 9)-11)}$ の Qmax/Qcu $-Q j u / Q c u$ 関係を図 16 に示す。

Qmax は最大耐力実験值，Qju は式(10)の接合部終局耐力時柱せん 断力, $Q \mathrm{ju} / \mathrm{Q}_{\mathrm{cu}}$ は接合部耐力余裕度を示す ${ }^{10)}$ 。式 (10) 中の Q au は主筋 定着耐力時柱せん断力であり, 正加力時の Qau は柱主筋定着耐力時 柱せん断力, 負加力時の Qau は柱または梁主筋定着耐力時柱せん断 力とした。同図中では，柱主筋外定着試験体で梁主筋本数のみが異 なる試験体同士を実線で結んだ。各耐力計算值は，表 2 の鉄筋の実 降伏点およびコンクリートの実圧縮強度を用いて求めた。

$$
\mathrm{Qju}_{\mathrm{u}}=\min (\mathrm{Qpu}, \mathrm{Qau})
$$

実験では，各試験体ともに，概ね，梁曲げ降伏が先行し，接合部 終局耐力時柱せん断力 $\mathrm{Qju}$ は接合部せん断終局耐力時柱せん断力 $\mathrm{Qpu}$ で決定した。図 16 によると, 正負加力時ともに, 柱主筋外定着, 柱 主筋内定着試験体に係わらず，最大耐力実験值 $Q \max$ は，Qju/Qcu $\geqq 1$ の場合 $Q_{c u}$ 以上となり，Qju/Qcu $<1$ の場合 $Q_{j u}$ 以上となった。すなわ ち，系列 $\mathrm{I} \sim \mathrm{IV} の$ 柱主筋外定着試験体の計算耐力 Qcu および Qju は， 柱主筋内定着試験体と同様，す心゙て最大耐力実験值 $Q \max$ に対して安 全側に評価された。

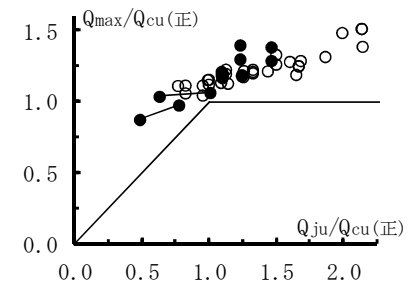

(a) 正加力時

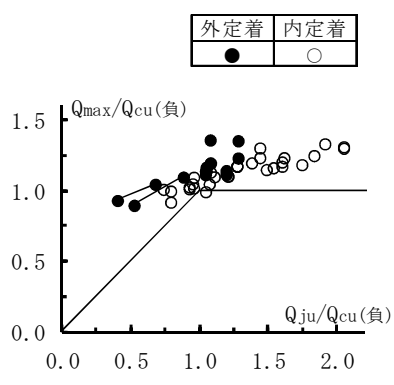

(b) 負加力時
図 $16 \mathrm{Qmax} / \mathrm{Qcu}_{\mathrm{c}}-\mathrm{Qju} / \mathrm{Q}_{\mathrm{cu}}$ 関係

\section{2 変形性能}

\section{2.1 接合部耐力余裕度の影響}

図 16 と同試験体の正負加力時 R80-Qju/Qcu 関係を図 17 に示す。 R80 は, 耐力が最大耐力 $Q_{\max }$ の 80\%に低下した時の限界層間変形角実 験值であり，同図中には，式(11)の接合部耐力余裕度 Qju/Qcu で決ま る限界層間変形角 R80a を併示した ${ }^{10)}$ 。

$\mathrm{R} 80 \mathrm{a}=0.03(\mathrm{Qju} / \mathrm{Qcu})$

図 17 によると, $Q \mathrm{ju} / \mathrm{Q}_{\mathrm{cu}} \geqq 1$ の場合，柱主筋外定着試験体の正加力 時 R80 は, 柱主筋内定着試験体の概ね R 80 の上限と一致し, 負加力時 のR80は，いずれも Qju/Qcuに係わらず $60 \times 10^{-3}$ 以上となった。 


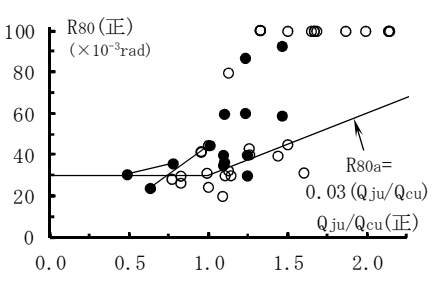

(a) 正加力時

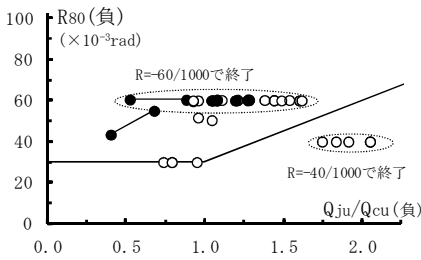

(b) 負加力時

図 $17 R 80-Q j u / Q c u$ 関係

\section{2.2 接合部横補強筋量の影響}

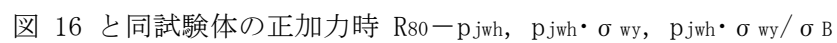
関係を図 18 に示す。pjwh は接合部横補強筋比, $\sigma$ wy は接合部横補強 筋の実降伏点, $\sigma$ B はコンクリートの実圧縮強度である。同図中で は, 柱主筋内定着試験体の場合, $785 \mathrm{~N} / \mathrm{mm}^{2}$ 級高強度せん断補強筋を 用い接合部横補強笳量 p jwh のみを変えた試験体同士を実線で結んだ。

柱主筋外定着試験体の場合, 3.2 節で前述したように, L 形が閉じ る正加力時には, 梁曲げ降伏後, 定着部拘束筋から接合部中央まで の横補強筋が引張降伏した。すなわち, 接合部横補強筋および定着 部拘束筋は, ともに梁曲げ降伏後の変形性能に対する補強効果を有 するので, 接合部横補強筋比は, 式(12)に示すように, 足し合わせ が成立すると考えられる。

これらより,図 18 では, pjwh は式(12)の等価横補強筋比 $\Sigma \mathrm{p} j \mathrm{wh}$ に, $\mathrm{pjwh} \cdot \sigma$ wy は等価横補強筋量 $\Sigma \mathrm{pjwh} \sigma$ wy にそれぞれ置き換えた。

$$
\begin{aligned}
& \Sigma \mathrm{pjwh}=\mathrm{pjwh}_{\mathrm{w}}+(\mathrm{p} \text { jwh })_{\mathrm{H}} \cdot \sigma \text { wyH } / \sigma \text { wy } \\
& \left(p_{j w h}\right)_{H}=n_{H} \cdot a_{w H} /\left(B_{c} \cdot j_{\text {tgo }}\right)
\end{aligned}
$$

$\left(\mathrm{p}_{\mathrm{jwh}}\right)_{\mathrm{H}}$ : 定着部拘束筋による横補強筋比

\section{$\sigma \mathrm{wyH}$ : 定着部拘束筋の降伏強度}

$\mathrm{nH}$ ：定着部拘束筋の組数, $\mathrm{awH}: 1$ 組の定着部拘束筋の断面積

Bc : 柱幅, jtgo：梁上下最外縁主筋の中心間距離

図 18 によると, 柱主筋内定着試験体の場合, 接合部耐力余裕度 $Q_{j u} / Q_{c u} \fallingdotseq 2$ の試験体を除くと, 正加力時 R 80 と接合部横補強筋量 $\mathrm{p}_{\mathrm{j} w h}$. $\sigma$ wy $/ \sigma$ B との相関性は, p jwh および p jwh・ $\sigma$ wy の場合よりもよい 9)。 また, 同一 $\mathrm{pjwh} \cdot \sigma \mathrm{wy} / \sigma \mathrm{B}$ の場合, 柱主筋外定着試験体の R 80 は, 接 合部横補強筋に $785 \mathrm{~N} / \mathrm{mm}^{2}$ 級高強度せん断補強筋を用いた柱主筋内 定着試験体の R 80 よりも大きく、接合部耐力余裕度 $Q_{j u} / Q_{c u} \fallingdotseq 2$ の場 合と同程度となった。

\section{2.3 保証限界層間変形角 R80min の評価}

接合部耐力余裕度 $Q j u / Q c u>0.9$ の柱主筋外定着試験体 11 体) および直交梁なしの柱主筋内定着試験体 ( $\bigcirc: 28$ 体) の正加力時の $\mathrm{R} 80 / \mathrm{R} 80 \mathrm{a}-\mathrm{pjwh} \cdot \sigma$ wy $/ \sigma$ B 関係を図 19, 正加力時 R80 と文献 9) 提案の 式(14)の保証限界層間変形角 R80min との関係を図 20 に示す。柱主筋 外定着試験体の場合, 図 18 と同様, 図 19 の接合部横補強筋量 pjwh . $\sigma$ wy は等価横補強筋量 $\Sigma \mathrm{p}$ jwh・ $\sigma$ wy に置き換えた。

$$
\begin{aligned}
& \text { R80min }=\text { R80a } \cdot \alpha \text { w } \\
& \alpha w=\alpha \text { wo }+\beta \text { w } \cdot\left(p_{j w h} \cdot \sigma \text { wy } / \sigma \text { B }\right) \\
& \alpha w, \alpha \text { wo, } \beta \text { w : 接合部横補強筋量による補正係数(表 3) }
\end{aligned}
$$

図 19 中には, 直交梁なしの柱主筋内定着試験体の実験值に対する 回帰式を一点鎖線, $\alpha$ wo $=0.6,0.8,1.2$ とした時の補正係数 $\alpha$ w を破 線で示した。同図からも, 正加力時 R 80 は, 接合部横補強筋量 $\mathrm{pjwh}$. $\sigma$ wy $/ \sigma$ B の影響を受けることが分かる。

図 20 に示寸ように, 柱主筋外定着試験体の限界層間変形角実験值 R80 は，概ね，保証限界層間変形角 R $80 \mathrm{~min}$ を上回り，柱主筋内定着試 験体の $\mathrm{R} 80$ の上限 (接合部横補強筋に $785 \mathrm{~N} / \mathrm{mm}^{2}$ 級高強度せん断補強筋 を用いた場合, あるいは接合部耐力余裕度が 2 程度の場合) と同程度 となった。すなわち, 柱主筋外定着による L 形部分架構の変形性能 は，柱主筋内定着よりも優れている。

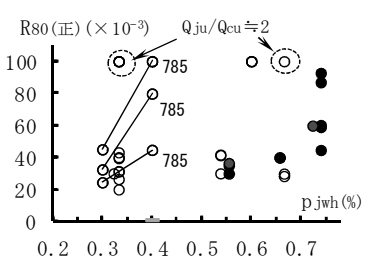

(a) R80-pjwh 関係

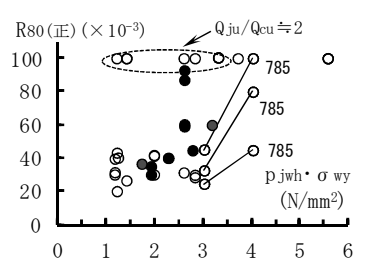

(b) $\mathrm{R} 80-\mathrm{pjwh} \cdot \sigma$ wy 関係

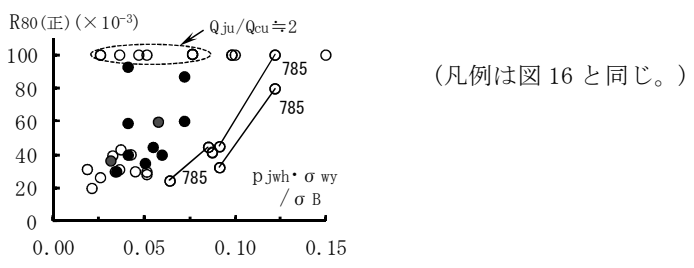

(c) R80-pjwh・ $\sigma$ wy $/ \sigma$ B 関係

図 $18 \mathrm{~L}$ 形部分架構の正加力時 R 80 に及ぼす接合部横補強筋の影響

表 3 接合部横補強筋量の補正係数 $\alpha$ wo, $\beta$ w

\begin{tabular}{|c|c|c|c|c|}
\hline & \multicolumn{3}{|c|}{$\alpha$ wo } & \multirow{2}{*}{$\beta$ w } \\
\cline { 2 - 3 } & $\begin{array}{c}\text { 直交梁 } \\
\text { なし }\end{array}$ & $\begin{array}{c}\text { 片側直交 } \\
\text { 梁付き }\end{array}$ & $\begin{array}{c}\text { 両側直交 } \\
\text { 梁付き }\end{array}$ & \\
\hline L形接合部 & 0.6 & 0.8 & 1.2 & 8.9 \\
\hline
\end{tabular}

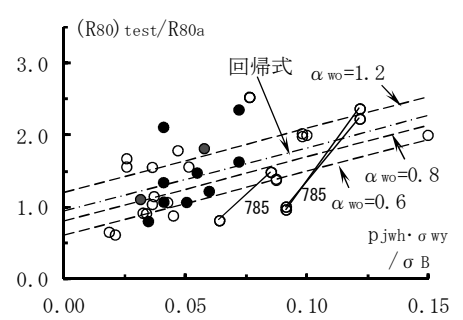

図 $19 \mathrm{R} 80 / \mathrm{R} 80 \mathrm{a}-\mathrm{pjwh} \cdot \sigma$ wy/ $\sigma$ B 関係

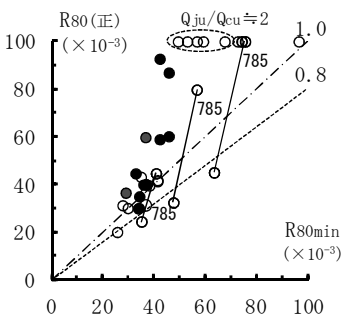

図 20 R80-R80min 関係

\section{5. 短期許容耐力時ひび割れ幅}

\section{1 検討方法}

$\mathrm{L}$ 形部分架構の短期許容而力時柱せん断力 $\mathrm{QaE}$ は, 梁主筋の規格 降伏点を短期許容引張応力度 $\mathrm{ftaE}$ とし, 式(16)の梁の短期許容曲げ 耐力時柱せん断力 cQga として算定する ${ }^{12), 13) 。 ~}$

$\mathrm{cQga}=\left\{2 \mathrm{Mgao} /\left(\eta \mathrm{ga} \cdot \ell_{\mathrm{o}}\right)\right\} \cdot(\ell / \mathrm{h}), \quad \eta \mathrm{ga}=1 \mp\left(\mathrm{jg}_{\mathrm{g}} \ell_{\mathrm{o}}\right) \cdot(\ell / \mathrm{h})$

上式中の干は，正加力時には一，負加力時には+とする。

$\mathrm{Mgao}_{\mathrm{g}}=\mathrm{Tga} \cdot \mathrm{jg}$ : 梁の基準短期許容曲げモーメント

Tga：引張側梁主筋の短期許容引張力

$\mathrm{jg}_{\mathrm{g}}(=7 / 8 \mathrm{dg})$ : 梁の応力中心距離, $\mathrm{dg}$ : 梁の有効せい

その他の記号は，4.1.1 項による。

短期許容耐力時の梁端曲げひび割れ幅 $\mathrm{WgaE}$ および接合部せん断 ひび割れ幅 WpaE は，それぞれクラックスケールを用いて測定した $\mathrm{R}=(1 / 200,1 / 100)$ 時の最大ひび割れ幅測定值 wg および wp をそれぞれ 直線補間して求めた ${ }^{12), 13)}$ 。 


\section{2 検討結果}

柱主筋外定着試験体 (14 体) とひび割れ幅測定值が得られた直交 梁なしの柱主筋内定着試験体 (30 体 $)^{4), 9)-13)}$ について, 短期許容耐力 時の梁端曲げひび割れ幅 $\mathrm{WgaE}$ および接合部せん断ひび割れ幅 $\mathrm{WpaE}$ と 接合部耐力余裕度 $Q j u / Q c u$ の関係を図 21 に示す。同図によると, 正 負加力時ともに, 柱主筋外定着試験体の $\mathrm{wgaE}$ および $\mathrm{wpaE}$ は, それぞ れ柱主筋内定着試験体と同程度の值であり，Qju/Qcu $\geqq 1$ の場合, 概 ね, wgaE は $1.0 \mathrm{~mm}$ 以下, $\mathrm{wpaE}$ は $0.4 \mathrm{~mm}$ 以下となった。

L 形部分架構の場合, 梁端曲げひび割れ, 接合部せん断ひび割れ ともに，短期許容耐力時ひび割れ幅に対する除荷時残留ひび割れ幅 の比は，それぞれ 0.5 程度である ${ }^{12), 13) 。 こ れ ら よ り, ~ Q ~ j u / Q ~} \mathrm{cu} \geqq 1$ の 場合, 柱主筋外定着, 柱主筋内定着試験体ともに, WgE および WpE の 上限は, 試験体の縮小率 $(1 / 2$ 程度)を考慮すると, それぞれ耐震性 能評価指針案 ${ }^{14}$ ) こよる修復限界状態 I（容易に補修しうる状態）の 残留ひび割れ幅の最大值 (梁端曲げひび割れ幅 $1.0 \mathrm{~mm}$, 接合部せん断 ひび割れ $0.5 \mathrm{~mm}$ ) に相当する。

すなわち，柱主筋外定着による L 形接合部についても，接合部耐 力余裕度 $Q j u / Q c u \geqq 1 の$ 場合, 所要の接合部配筋詳細とすれば, 柱梁 接合部に修復性を損なうひび割れは発生しないと考えられる。
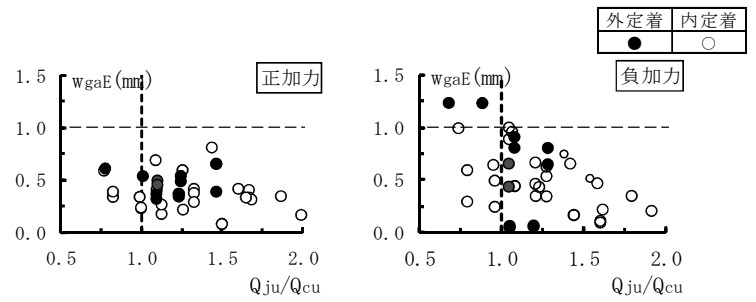

(a) 梁端曲げひび割れ幅
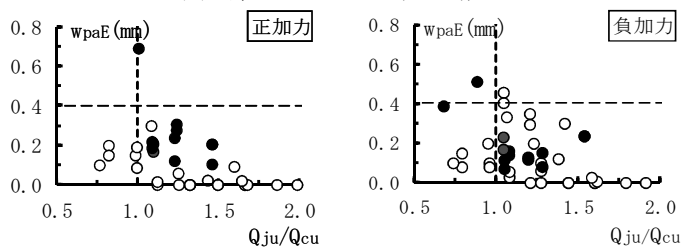

（b）接合部せん断ひび割れ幅

図 21 短期許容耐力時ひび割れ幅

\section{6. まとめ}

本論文では，筆者ら提案の柱主筋外定着方式 ${ }^{4), 5)}$ による L 形接合 部の実験を基に，以下の知見を得た。

1）系列 I 〜 IVの柱主筋外定着方式試験体では，式(1)の梁または柱 の曲げ終局耐力時柱せん断力 Qcu および式(10)の接合部終局耐 力時柱せん断力 $\mathrm{Qju}$ は, 従来の柱主筋内定着方式と同様, すべて 最大耐力実験值 $Q$ max に対して安全側に評価された。

2）限界層間変形角 R80 の正加力時実験值は, 同一保証限界層間変形 角 R80min の場合，柱主筋内定着方式よりも明らかに大きい。す なわち，柱主筋外定着による L 形部分架構の変形性能は，柱主 筋内定着よりも優れている。

3）梁曲げ降伏先行型の場合，最大耐力時の引張力伝達係数 $\gamma \mathrm{Hg}$ は 引張力基準伝達係数 $\gamma$ Hgo と同程度となり, 引張力伝達係数 $\gamma \mathrm{Hc}$ は引張力基準伝達係数 $\gamma$ Hco に漸近した。

$\gamma \mathrm{Hg}$ は接合部仕口面での梁上端筋に対する定着部拘束筋の全 引張力の比 $(\mathrm{TH} / \mathrm{Tg}), \quad \gamma \mathrm{Hc}$ は接合部仕口面での最外縁柱主筋に対
する定着部拘束筋の全引張力の比 $\left(\mathrm{TH} / \mathrm{T}_{\mathrm{cf}}\right)$ として定義される。

4） 3) 項の知見によると, 本実験範囲の引張力基準伝達係数 $\gamma$ Hgo $の$ 定着部拘束筋を配置すれば、柱主筋外定着方式の梁曲げ降伏先 行型 L 形接合部の場合，式(12)の等価横補強筋比 $\Sigma \mathrm{pjwh}$ のよう に，接合部横補強筋と定着部拘束筋との足し合わせが成立し， 柱主筋外定着方式の保証限界層間変形角 R80min は，柱主筋内定 着方式と同様，式(14)で評価できる。

5）梁の短期許容曲げ而力時の梁端曲げひび割れ幅 WgaE および接合 部せん断ひび割れ幅 WpaE は，柱主筋内定着方式と同様，耐震性 能評価指針案 ${ }^{14}$ )による修復限界状態 I（容易に補修しうる状態） に留まった。

\section{謝辞}

本実験は，(株) 伊藤製鐵所，共英製鋼 (株)，JFE 条鋼 (株)，ブイ・ エス・エル・ジャパン(株)の開発実験として行ったものであり，こ こに記して謝意を表する。

\section{参考文献}

1） 日本建築学会 : 鉄筋コンクリート造配筋指針・同解説 付録 A5. 機械式 定着工法による接合部配筋詳細の納まり検討の要点, pp. 311-330， 2010

2）益尾潔，井上寿也，岡村信也：機械式定着工法による RC 造 T 形および $\mathrm{L}$ 形柱梁接合部の終局耐力に関する設計条件、日本建築学会構造系論文集, 第 590 号，pp. 95-102，2005. 4

3）日本建築学会: 鉄筋コンクリート構造計算規準・同解説 17 条, pp. 229-256, 2010

4）田川浩之，堂下航，足立将人，益尾潔 : 機械式柱主筋·外定着による RC 造最上階 T 形、L 形柱梁接合部の実験, GBRC, Vol. 36, No. 1, pp. 32-39, 2011. 1

5）益尾潔，田川浩之，山下利法，小寺耕一郎，丸山透 : 機械式柱主筋外定 着による RC 造 L 形柱梁接合部の構造性能一続報 $1 、 2-$, 日本建築学会 大会学術講演梗概集, 構造IV, pp. 531-534, 2012.9

6）加藤史明，清原俊彦，田才晃，楠浩一：機械式定着を用いた RC 造最上 階 L 形柱梁接合部の構造方式に関する実験的研究，コンクリート工学年 次論文集, Vol. 33, No. 2, pp. 289-294, 2011

7）吉村匡裕，加藤史明，田才晃ほか 3 名：機械式定着を用いた RC 造 L 形 柱梁接合部の柱頭部拘束筋の効果に関する実験的研究，その 1 , その 2 , 日本建築学会大会学術講演梗概集, 構造IV, pp. 481-484, 2011

8）益尾潔，足立将人，田川浩之：機械式定着による $\mathrm{RC}$ 造小梁主筋の定着耐 力および必要定着長さ，日本建築学会構造系論文集，第 631 号， pp. 1625-1632，2008.9

9）益尾潔，井上寿也，岡村信也：機械式定着工法による RC 造 T 形および $\mathrm{L}$ 形柱梁接合部の終局耐力に関する設計条件, 日本建築学会構造系論文集, 第 590 号，pp. 95-102，2005. 4

10）益尾潔，足立将人：機械式定着による柱主筋定着耐力ならびに RC 造 T 形、L 形部分架構の変形性能, コンクリート工学年次論文集, Vol. 31, No. 2, pp. 343-348，2009. 7

11）足立将人，益尾潔：機械式定着工法による RC 造 T 形および $\mathrm{L}$ 形柱梁部分 架構の構造性能に及ぼす直交梁の影響，コンクリート工学年次論文集， Vol. 31, No. 2, pp. 337-342, 2009.7

12）益尾潔，井上寿也，足立将人：機械式定着工法による卜形， T 形， L 形 接合部のひび割れ損傷の評価（その 1 その 3)，日本建築学会大会学術 講演梗概集，構造IV，pp. 271-276，2005.8

13）益尾潔，田川浩之，足立将人：機械式定着による SRC 造 T 形および $\mathrm{L}$ 形 柱梁接合部の終局耐力に関する設計条件，日本建築学会構造系論文集， 第 637 号, pp. 543-550, 2009. 3

14）日本建築学会 : 鉄筋コンクリート造建物の耐震性能評価指針 (案) ・同解 説，6. 柱部材の性能評価法、8. 柱梁接合部の性能評価法, pp. 169-194, pp. $232-247,2004.1$ 